\title{
The Impact of Information and Communication Technology on Interorganizational Coordination: Guidelines from Theory
}

\author{
Mariëlle den Hengst and Henk G. Sol \\ Delft University of Technology, the Netherlands
}

\author{
m.den.hengst@tpm.tudelft.nl h.g.sol@tpm.tudelft.nl
}

\begin{abstract}
It is widely believed that information and communication technology (ICT) enables organizations to decrease costs and increase capabilities and thus enables to shape interorganizational coordination. This paper describes guidelines with which the impact of ICT on interorganizational coordination structures can be predicted. The framework used consists of three perspectives: interorganizational coordination structures, ICT, and aspects of goods and services for the processing of which coordination is required. Interorganizational coordination structures are defined and the impact of ICT on coordination structures is indicated. So far, ICT is considered to be a driving force. There are, however, other aspects that have an influencing impact on interorganizational coordination. Those aspects are described and by combining those with the possibilities of ICT, the guidelines are presented.
\end{abstract}

Keywords: information and communication technology, interorganizational coordination, coordination structures

\section{Introduction}

Organizations must continuously change due to ongoing changes in the environment (Donaldson, 1996). In trying to improve the performance of the organization, the focus has shifted over the past years from the organizational level towards the interorganizational level (Malone and Rockart, 1991; McGrath and Hollingshead, 1994). This growing interest in interorganizational relationships can be illustrated by several interrelated business trends (Bowersox and Closs, 1996), some of which are presented below.

- A first business trend is the use of information and communication technology (ICT) to decrease costs and increase capabilities (Malone and Crowston, 1994). Developments in ICT such as the World Wide Web, Electronic Data Interchange, and electronic mail can be seen as enablers to cross organizational boundaries more easily when dealing with information intensive processes. From the early efforts to support

Material published as part of this journal, either on-line or in print, is copyrighted by the publisher of Informing Science. Permission to make digital or paper copy of part or all of these works for personal or classroom use is granted without fee provided that the copies are not made or distributed for profit or commercial advantage AND that copies 1) bear this notice in full and 2) give the full citation on the first page. It is permissible to abstract these works so long as credit is given. To copy in all other cases or to republish or to post on a server or to redistribute to lists requires specific permission and payment of a fee. Contact Editor@inform.nu to request redistribution permission. existing interorganizational processes (e.g. the exchange of documents between organizations), the focus has shifted to the emergence of new ways of doing business. Examples of this include the introduction of electronic trading markets, electronic auctions, and electronic bookstores. ICT has developed from a minor force supporting the interorganizational processes into a dominant force for shaping these processes.

- Outsourcing of secondary activities is another business trend (I\&L, 1997). Organizations concentrate on their core business and specialize in main activities to reduce costs. This is a consequence of operating in a turbulent environment (Thompson, 1967). Turbulence consists of two components: instability and randomness (Huber and Daft, 1987). Instability refers to the frequency of change. Randomness refers to the unpredictability of both the frequency and direction of change.

- Globalization as a business trend has been realized by international trade agreements such as the European Union, the General Agreement on Tariffs and Trade (GATT), and the North American Free Trade Agreement (NAFTA). This has resulted in a worldwide market in which organizations must compete.

The business trends mentioned above indicate changes especially at the interorganizational level: increasing and changing communication between organizations, shifting organizational boundaries, and geographically expanding 
The Impact of ICT

relationships between organizations. Although different in nature, the changes all affect the coordination between organizations (Vreede, 1995). Since a positive relationship exists between the range of benefits obtained from coordination and the level of ICT support (Venkatraman, 1994), guidelines need to be designed for new combinations of coordination and ICT at an interorganizational level. The focus of this paper is on interorganizational coordination structures, which will be elaborated on later in this paper. Several proven theories and technologies have been used to design these guidelines. To consistently review literature and come up with the guidelines, a framework has been used. The framework is presented in section 2 . The framework consists of three perspectives, each of which will be discussed in a separate section (section 3, 4, and 5). By combining the notions on the three perspectives, guidelines are presented with which the impact of ICT on interorganizational coordination structures can be predicted (section 6). The paper ends with conclusions and recommendations for future research.

\section{Research Framework}

The impact of ICT on interorganizational coordination can not be defined easily, since coordination structures can not be prescribed but have to evolve over time. However, it is expected that some guidelines can be distilled from theory to predict the impact of ICT on interorganizational coordination structures. A framework has been used to consistently come up with the guidelines. The framework consists of three perspectives (Hengst, 1999). The first perspective focuses on coordination structures as being the subject of research. The second perspective describes the use of ICT as having the potential to change coordination structures. So far, ICT is considered to be a driving force in changing coordination structures. There are, however, other aspects that have an influencing impact on interorganizational coordination. These aspects are considered under the third perspective. The coordination structures and the ICT support that will be optimal in a given situation depend on several aspects of the goods or services being produced and supplied (Bailey and Bakos, 1997).

Figure 1 demonstrates that the three perspectives are interrelated and have an influencing impact on each other. The sections that follow will elaborate on each of the three perspectives and will also describe the influencing impact that each of the perspectives has on the other perspectives.

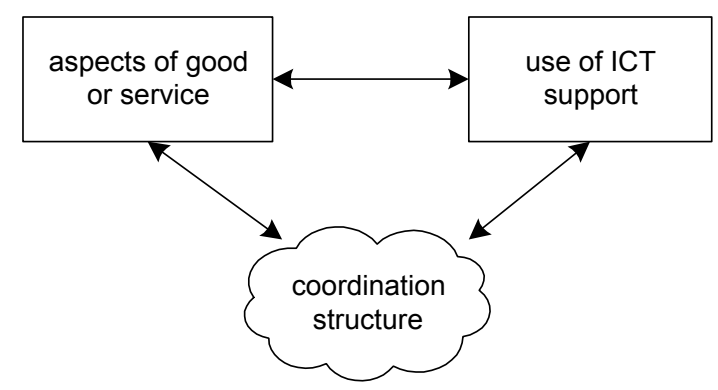

Figure 1: The interrelated perspectives

\section{Interorganizational Coordination Structures}

The need for coordination arises as a logical consequence for the division of labor in and between organizations (Mintzberg, 1993). A general definition of coordination is proposed by Malone and Crowston (1994): 'coordination is managing dependencies'. Several mechanisms are available to manage dependencies. Several authors describe coordination processes [e.g. Kumar, 1996; Malone and Crowston, 1994; Mintzberg, 1993; Thompson, 1967; Winograd \& Flores, 1986). Processes are, however, not the only mechanisms to achieve coordination. The structure of a group of organizations can also be seen as a mechanism for coordinating activities (Jablin, 1987). The focus of this paper is on coordination structures. A structure, at an abstract level, can be viewed as a collection of elements and the set of relationships that connect these elements (Monge \& Eisenberg, 1987). In an interorganizational coordination structure, the elements are the organizations. The relationships between those organizations can be associated with different perspectives such as dyads, chains, industries, and networks (Clegg and Hardy, 1996; Kambil, 1992). These perspectives are visualized in figure 2. Organizations that are members of the same type of industry are labeled with the same letter in this figure. The goods or services flow from $\mathrm{A}$ to $\mathrm{C}$.

- Dyad. The dyad perspective refers to the relationship between two organizations, a supplier and a buyer. The dyad perspective was not considered since the chain optimized as a whole will be better off than a set of optimized dyads (Sterman, 1989).

- Chain. The dyad perspective can be extended to the chain perspective by incorporating the supplier of the supplier and so on; a chain consists of two or more dyads. The chain is thus the sequence of primary processes associated with the transformation of the 'good' from raw materials through to the finished product for the final customer.

- Industry. The industry refers to relationships based on competition. Organizations in the same industry offer 


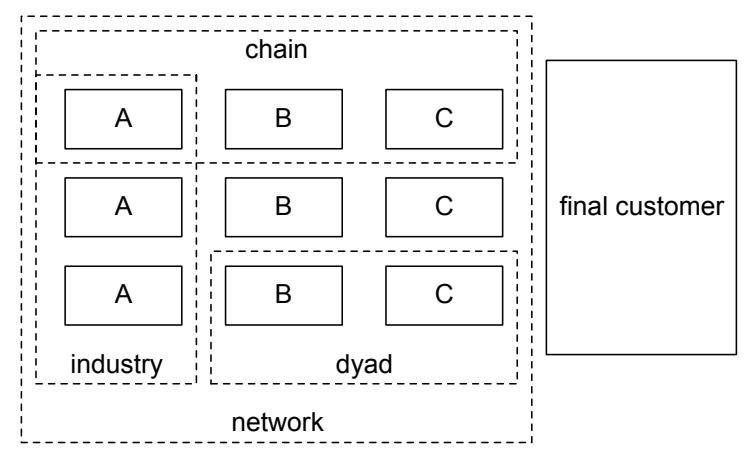

\section{Figure 2: Perspectives for interorganizational relationships}

products or services that are close substitutes (Kotler, 1994; Porter, 1980). The structure of an industry depends on several characteristics such as concentration, level of product differentiation, and barriers to entry (Barney \& Hesterly, 1996).

- Network. The network perspective stresses the web that is created by all the interdependencies between the processes of different organizations, including competitive relationships as in the industry and supplier-buyer relationships as in chains.

The chain perspective was used in this research as a temporary arrangement of organizations in a network. This is explained by the theory of dynamic networks and temporary chains (Jarvenpaa \& Ives, 1994; Miles \& Snow, 1992). A chain is an arrangement of organizations in a network for the fulfillment of a customer order. After fulfillment, the chain can be dissolved and the organizations in the network are ready to form new chains.

There are many different types of interorganizational coordination structures, but they can be categorized into two basic coordination structures (Malone et al., 1987; Thompson et al., 1991). A hierarchical coordination structure is characterized by long lasting relationships between organizations with fixed rules of behavior and clear authority relationships. One organization has control over the other organizations. The market as a structure coordinates organizations via bidding and pricing systems. In a real market organizations have to build a relationship for every new customer order. All organizations are fully autonomous and make decisions in their own interest. Market coordination relies mainly on price mechanisms, while hierarchical coordination mainly uses authority and other procedural coordination processes. The dichotomy of markets and hierarchies is not as sharp as it may seem. The actual mix of coordination mechanisms to be used in practice can be characterized as hybrid (Powell, 1991). Hybrids vary between the extremes of pure markets and pure hierarchies. The division into these three coordination structures is insufficient. A more detailed prediction should be possible than saying that the use of ICT may lead to proportionally extra use of markets (Malone et al., 1987). Four aspects of coordination structures are identified for this purpose: centralized versus decentralized, dominated versus neutral, the number of participants, and long term versus short term agreements. Markets can be characterized as neutral, with a large number of participants, and with short term agreements. Strict hierarchies have a dominated structure, often with a few participants, and with long term agreements. Both markets and hierarchies can be centralized or decentralized, although Brynjolfsson (1994) states that mostly centralized coordination will optimally take place within hierarchies.

1. Coordination structures can be classified into decentralized and centralized structures (Malone \& Crowston, 1994). In a decentralized structure, all buyers are able to contact all sellers to negotiate transactions, whereas in a centralized structure transactions between buyers and sellers are negotiated indirectly through a broker. Different types of centralized structures can be distinguished when taking into account on who's behalf the broker operates: on behalf of a buyer, on behalf of a group of buyers, on behalf of a seller, on behalf of a group of sellers, or independently of both buyers and sellers. The types of centralized and decentralized structures are presented in table 1.

\begin{tabular}{|c|c|c|c|c|}
\hline \multicolumn{2}{|c|}{ independently } & \multirow{2}{*}{ seller } & \multicolumn{2}{|l|}{ broker } \\
\hline \multicolumn{2}{|c|}{ centralized } & & one seller & $\begin{array}{l}\text { group of } \\
\text { sellers }\end{array}$ \\
\hline \multicolumn{2}{|c|}{ buyer } & decentralized & centralized & centralized \\
\hline \multirow{2}{*}{$\begin{array}{l}\text { bro } \\
\text { ker }\end{array}$} & one buyer & centralized & centralized & centralized \\
\hline & $\begin{array}{l}\text { group of } \\
\text { buyers }\end{array}$ & centralized & centralized & centralized \\
\hline
\end{tabular}

Table 1: Classification of coordination structures

2. The aspect of the coordination structure being dominated or neutral takes into consideration the power of setting prices and rules (Bodendorf \& Reinheimer, 1997). In a dominated structure, one organization sets the prices and rules and it is up to the other organization either to accept this or not to agree on the deal. In contrast, a neutral structure enables organizations to introduce their prices and rules and to negotiate them among each other.

3. The third aspect takes into consideration the number of buyers or sellers that take part in the coordination 
and can vary between one organization and the total number of buyers or sellers in the network. A distinction is made between the number of participants in the network with whom agreements are negotiated and the number of participants with whom agreements are settled to form a chain. The number of participants in the network taken into account can influence the results of the negotiations (Kalakota \& Whinston, 1996; Porter, 1980): the more participants that take part in the negotiations, the better supply and demand can be coordinated. Williamson (1975) argues that while the number of participants is high the first time negotiations take place between the participants, it is often much lower in renewal stages. The number of participants with whom an agreement is settled can be lower than the number with whom is being negotiated.

4. Organizations make agreements about a certain good or service. This agreement could be valid for once only (short term) or for a longer period of time in which the good or service is required more than once (long term) (Williamson, 1985).

These aspects appeared to be sufficient to describe different coordination structures in practice. Table 2 shows three examples from practice to illustrate this. The division between markets, hybrids, and hierarchies can not indicate the differences between the coordination structures in these examples.

\begin{tabular}{|l|l|l|l|}
\cline { 2 - 4 } \multicolumn{1}{c|}{} & $\begin{array}{l}\text { Passenger } \\
\text { transport } \\
\text { by air }\end{array}$ & $\begin{array}{l}\text { Production } \\
\text { of cars }\end{array}$ & $\begin{array}{l}\text { Inland } \\
\text { container } \\
\text { transport }\end{array}$ \\
\hline $\begin{array}{l}\text { centralized- } \\
\text { decentral- } \\
\text { ized }\end{array}$ & centralized & decentralized & $\begin{array}{l}\text { centralized/ } \\
\text { decentral- } \\
\text { ized }\end{array}$ \\
\hline $\begin{array}{l}\text { dominated- } \\
\text { neutral }\end{array}$ & dominated & neutral & neutral \\
\hline $\begin{array}{l}\text { \# partici- } \\
\text { pants nego- } \\
\text { tiating }\end{array}$ & high & low & high \\
\hline $\begin{array}{l}\text { \# partici- } \\
\text { pants settled }\end{array}$ & low & low & low \\
\hline $\begin{array}{l}\text { long term - } \\
\text { short term }\end{array}$ & short term & long term & long term \\
\hline
\end{tabular}

Table 2: Examples of coordination structures

\section{The Impact of ICT}

It has been mentioned in the first section that the use of ICT may have a positive impact on coordination. It is widely believed that the use of ICT, therefore, enables people to shape coordination (Bodendorf \& Reinheimer, 1997; Malone \& Rockart, 1991; Malone \& Crowston, 1994): more effective and more efficient coordination processes, more coordination processes, and new coordination structures. Since the use of ICT can lower coordination costs, this may lead to an overall shift towards smaller firms and proportionally extra use of markets (Malone et al., 1987). Increased outsourcing can be identified and at the same time the use of ICT can facilitate an increase in the number of organizations involved (Williamson, 1975, 1986). This notion is elaborated on below with attention paid to the causes of the uses of ICT for the four aspects of coordination structures.

Coordination structures will become more centralized thanks to the use of ICT. On first thoughts it seems to be the other way around. Assume $n$ buyers and $m$ sellers. In a decentralized structure, each buyer can contact at most $m$ sellers and each seller at most $n$ buyers. This would result in at most $n * m$ communication lines. In a centralized structure, communication takes place indirectly through a broker resulting in at most $n+m$ communication lines on the basis of a single broker (see figure 3 ). There is only one communication line for each buyer and seller in this case. When $k$ brokers are present, the maximum number of lines will be $k^{*}(n+m)$, which can be more than $n^{*} m$. The number of contacts for each buyer and seller will, however, usually be less than $m$, respectively $n$, as in the decentralized structure. As a result of a reduction in coordination costs, more decentralized structures will come within reach of buyers and sellers (Hines, 1993; Moore, 1993). Although the use of ICT lowers coordination costs, it also increases the complexity of coordination: more coordination processes are used and more organizations are involved resulting in more communication activities and in more information to be taken into account when making a decision. An additional result, therefore, is that more and more information becomes available. The World Wide Web is a good example of this. The more information available, the more difficult it gets to find the right information. Eventually, the decentralized structure will turn back into a centralized structure in which one or more brokers can satisfy the need for information required for coordination (Bakos, 1998; Kornelius \& Ekering, 1994; Malone \& Rockart, 1991; Moore, 1996). 


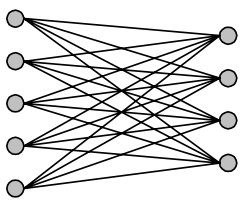

buyers sellers decentralized

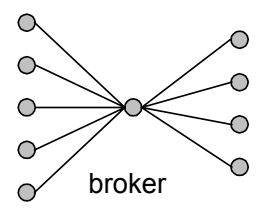

buyers sellers centralized single broker

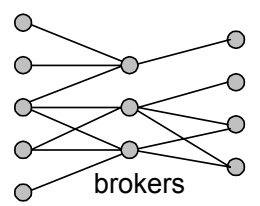

buyers sellers centralized $k$ brokers
Figure 3: Centralized versus decentralized coordination structures

The use of ICT is not expected to influence the aspect of dominated versus neutral. A dominated structure will stay dominated and a neutral structure will stay neutral. Within a neutral structure, however, some changes can take place. Bakos $(1991,1997)$ shows that by reducing coordination costs ICT will improve the efficiency of a neutral coordination structure, but will reduce the profit of the participants. If the costs of coordination are low enough, buyers can compare all offers and select the one best serving their needs. They enjoy low prices because of the increased competition among the sellers. For this reason, sellers are willing to prevent the introduction of ICT; however, eventually it is impossible to avoid the usage of ICT. Bakos (1997) suggests three strategies to be used by sellers to minimize the negative effect: emphasizing service over price information, making it increasingly difficult to compare the price of alternative offerings, for example by everchanging fare structures, and increasing the differentiation of offerings.

The number of participants is analyzed by looking separately at negotiating and settling agreements. The number of participants during the negotiation phase will increase thanks to the use of ICT (Bakos, 1991). The optimal number of participants to contact is determined by trading off coordination costs for further searches for new participants against the expected benefit from identifying a better participant (Bakos \& Brynjolfsson, 1993). The use of ICT is believed to reduce the costs of coordination (Malone et al., 1987) and as thus lead to more participants (Kalakota \& Whinston, 1996). This trend, however, is not yet recognized in practice, instead the opposite is happening: the number of participants has decreased over the past years (Bakos \& Brynjolfsson, 1993). The adoption of ICT currently requires organizations to make large, technological and organizational investments to connect to each new participant. This may explain why the number of participants decreased. It is widely believed, however, that in the long run ICT lowers coordination costs and that the number of participants contacted during negotiations will increase. This however, is no guarantee that the number of organizations with which an agreement is settled will in- crease. The number of organizations depends not only on coordination costs, but also on aspects such as the amount of relation specific investments, the quality, the trust and the flexibility (Bakos \& Brynjolfsson, 1993), see also next section. Nevertheless, it is expected that the number of participants with whom agreements are settled will increase from an ICT oriented perspective.

The use of ICT can also influence the duration of agreements. To build a relationship with an organization requires some investments, for example in information systems to share information. If the investments are high, it is not profitable to do this over and over again for every order. Long term agreements are settled in which the good or service can be supplied more than once. With the ongoing developments in ICT such as the process of standardization, the investments required will become lower. This could eventually lead to agreements for a shorter period of time.

Summarized, the use of ICT is assumed to change three coordination structure aspects: a more centralized structure is expected in which more organizations participate and in which agreements are settled for a shorter period of time. The use of ICT will provide the possibility to change the coordination structure to a more market-like structure. In the expectations ventilated above ICT is considered to be the driving force. There are, however, other aspects that have an influencing impact on interorganizational coordination. These aspects are discussed in the next section.

\section{Influencing Aspects}

The coordination structures and the ICT support that will be optimal in a given situation depend on several aspects of the goods or services being produced and supplied (Bailey $\&$ Bakos, 1997). Although there is not a one-to-one relationship between the aspects and interorganizational coordination, some indications can be given, see for example Rosenschein and Zlotkin (1994).

The first aspect concerns homogeneity. The more factors there are that need to be considered to distinguish goods or services from each other, the more complicated the comparison becomes (Bodendorf \& Reinheimer, 1997). Besides price, other factors are the size, the weight and the amount of goods, and qualitative issues such as the responsiveness and the flexibility of the service. These factors define the preference profiles on both the buyer and the supplier side. When too many factors are required to define the profiles, this job is left to a third party, a broker, resulting in a more centralized structure (Bodendorf \& Reinheimer, 1997). When only a few factors are required, a decentralized structure can be used. Malone et al. (1987) 
add to this that the greater the number of factors needed, the longer the relationships will last and the lower the number of participants will be. Furthermore, the homogeneity aspect influences the use of ICT support. The more factors that need to be considered, the greater the impact of bounded rationality, the more time consuming it is, and there are more errors that can be made. ICT based systems to support communication and decision making can be used in this case.

The aspect specificity refers to the degree to which the relationship between a buyer and a seller will produce an asset that is dedicated to a special purpose with poor alternative uses (Williamson, 1986): non-contractible relationspecific investments (Bakos \& Brynjolfsson, 1993). Williamson (1983) identifies different types of specificity. Physical asset specificity refers to how specialized the equipment must be. Human-capital specificity refers to how specialized the required knowledge and expertise must be. Site specificity deals with the fact that a buyer and a seller are in a 'cheek-by-jowl' relation, reflecting ex ante decisions to minimize inventory and transport expenses. Dedicated asset specificity refers to general investments that would not take place for the prospect of selling a significant amount of product to a particular customer. If the contract were to be terminated prematurely, it would leave the supplier with dedicated asset capacity. If the degree of specificity is low, the buyer should adopt the maximum feasible number of sellers (Bakos \& Brynjolfsson, 1993), or the seller should adopt the maximum feasible number of buyers. If the degree of specificity is high, the buyer should employ relatively few sellers and the other way around. Besides the number of participants, the duration of agreements is also influenced. The more specific investments that must be made, the longer the period of agreement will be. Malone et al. (1987) add to this that a centralized structure is in favor to address problems of asset specificity.

Time pressure exists for all goods and services since if it does not matter when the good or service is sold, it would not matter whether they were sold at all (Cramton, 1991). The degree of time pressure, however, can differ among different goods and services. Most goods can be stored and are, therefore, hardly under any time pressure, whereas services are hard to store. While for goods there is a chance not to sell at a certain moment but later, services must be sold before they are carried out. Under no time pressure the possibility exists to contact a large amount of sellers or buyers, where under pressure no time might be available to do this. The number of participants is restricted by the time available. Time pressure also influences the duration of agreements. When time pressure is quite high, negotiating could take up too much time. Long lasting agreements are more preferable in that case. The aspect time pressure also influences the use of ICT support. It is expected that ICT can speed up time in communication and decision making processes. The advantages of using ICT support can be considerable under time pressure.

Goods or services can have a high value for an organization, for example when it concerns a critical purchase. Trust in the relationship is an important factor in these situations (Levacic, 1991). Sellers or buyers are inclined to only a few participants and long lasting relationships to build a relationship of trust.

Frequency refers to how often a good or service is required, either occasionally or recurrently (Williamson, 1986). The duration of an agreement and the number of participants is influenced by the frequency. The greater the frequency, the better long term contracts with only a few participants since it would become too costly if agreements must be settled each time a good or service is required.

Uncertainty is defined as the difference between the information at hand and the information needed to make a decision (Galbraith, 1977). Uncertainty may be high as a result of an unpredictable network because it is uncertain how the actual demand patterns will evolve and because there is no guarantee that the suppliers will perform as agreed (Roy, 1988; Williamson, 1985). Another cause for uncertainty is that environmental changes such as technological and economic trends are unknown (Roy, 1988; Williamson, 1975). There are two strategies to deal with uncertainty (Galbraith, 1977): improve the information processing or reduce the need for information. The information processing can be improved by the use of ICT support. The need for information can be reduced by using slack resources and by increasing flexibility (Fisher, 1997). If, despite applying these strategies, uncertainty still is high long lasting relationships with only a few participants prevail (Williamson, 1975).

Summarized, six aspects were identified that influence the way in which interorganizational coordination can be carried out: homogeneity, specificity, time pressure, value, frequency, and uncertainty. One aspect that is often mentioned in the literature and that is not explicitly taken into account here is the relationship of trust. The reason for this is that trust is considered a result of the aspects of the good or service: for high value goods or services that are under time pressure, that have a high frequency, and for which the level of uncertainty is high, trust is considered to be 
important. Long term arrangements prevail over short term arrangements to build a relationship of trust.

\section{Guidelines Overview}

Although coordination structures can not be prescribed but have to evolve over time, some guidelines can be distilled from the notions in the previous sections. The three perspectives described in the previous section can be placed in a causal diagram (figure 4). The elements that are of importance were distilled from literature in the previous sections and are placed in the ovals. The elements have an influencing impact on each other. The direction of the influencing impact are described and supported by literature in the previous sections. The height of the impact, however, is hard to predict, for example: will the number of participants double or triple when time pressure is lowered or when more (advanced) ICT is used? To get grip on the height of the impact, empirical research is required to collect evidence on this. Furthermore, the use of ICT should be elaborated on in more detail, for example: the impact of using email probably will be different from the impact of using software agents.

Another challenge that is not dealt with yet, are the 'contradictions' in the causal diagram, for example: the use of ICT leads to more participants, while the aspects of the good or service indicate that a few participants are better given the situation. Once the height of the height of the impact is known, these contradictions will become more clear as well.

Although not fully developed yet, the causal diagram presented in figure 4 can be used in practice to get feeling of the coordination structures after introducing ICT to support the coordination. First, one should get an idea of the coordination structure in the current situation. Second, it is important to analyze the aspects of the goods or services being produced and supplied. The third step is the most important one, but also most difficult one: one should elaborate the influence of using ICT on the coordination structure as well as on the aspects. By doing this, one gets a first insight into the coordination structures that might evolve.

\section{Conclusions and Further Research}

The impact of ICT on interorganizational coordination has been explicated by designing some guidelines for coordination structures. Based on application of the guidelines, they should be valuated. For a thorough evaluation of the designed guidelines for interorganizational coordination, they should be applied to various application areas, such

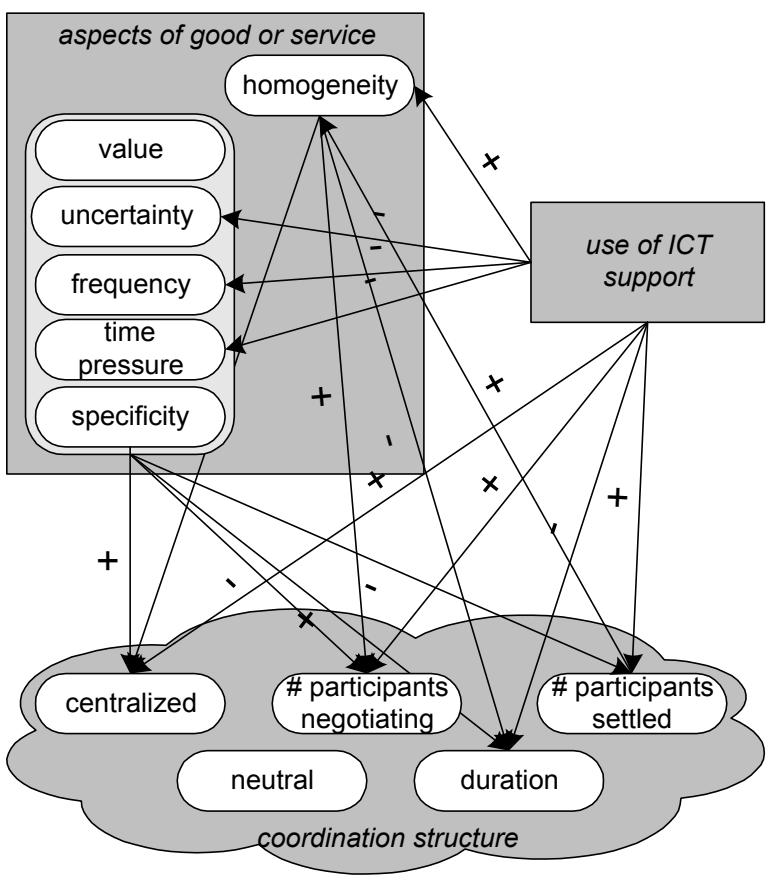

Figure 4: Interorganizational coordination structures and the influencing impacts

as the transport industry, the production industry, and the service industry.

Another interesting research area to further explore would concern the actual change in the coordination structure. With the guidelines given in this paper, a prediction of a coordination structure can be given. But as said earlier, a coordination structure can not be prescribed, but has to evolve over time. Further research could focus on the question how this process of change takes place and how one can intervene in this process, if possible at all.

Furthermore, the focus of this paper was on interorganizational coordination structures. Coordination processes were left aside, but ICT could have a tremendous impact on the processes as well. Much research is already taking place on this subject, but interesting to see is how this would combine with the research described in this paper.

\section{References}

Bailey, J. P., \& Bakos, J. Y. (1997). 'An Exploratory Study of the Emerging Role of Electronic Intermediaries'. International Journal of Electronic Commerce, no. 3, vol. 1, 7-20.

Bakos, J.Y. (1991). 'Information Links and Electronic Marketplaces: The Role of Interorganizational Information Systems in Vertical Markets'. Journal of Management Information Systems, no. 2, vol. 8 . 
The Impact of ICT

Bakos, J.Y. (1997). 'Reducing Buyer Search Costs: Implications for Electronic Marketplaces'. Management Science, no. 12, vol. 43.

Bakos, J.Y. (1998). 'The Emerging Role of Electronic Marketplaces on the Internet'. Communications of the ACM, 14.

Bakos, J.Y., \& Brynjolfsson, E. (1993). 'Information Technology, Incentives, and the Optimal Number of Suppliers'. Journal of Management Information Systems, no. 2, vol. 10, 37-53.

Barney, J.B., \& Hesterly, W. (1996). 'Organizational Economics: Understanding the Relationship between Organizations and Economic Analysis'. Handbook of Organization Studies, S.R. Clegg, C. Hardy, and W.R. Nord (editors), Sage Publications, London, United Kingdom, 115-147.

Bodendorf, F., \& Reinheimer, S. (1997). 'Offer Evaluation in an Electronic Air Cargo Market'. Proceedings of the Fifth European Conference on Information Systems (ECIS'97), 868-881.

Bowersox, D.J., \&. Closs, D.J. (1996). Logistical Management. The Integrated Supply Chain Process, McGraw-Hill, New York, USA.

Brynjolfsson, E. (1994). 'An Incomplete Contracts Theory of Information, Technology and Organization'. Management Science.

Clegg, S.R., \& Hardy, C. (1996). 'Organizations, Organization and Organizing'. Handbook of Organization Studies, S.R. Clegg, C. Hardy, and W.R. Nord (editors), Sage Publications, London, United Kingdom, 1-28.

Cramton, P.C. (1991). 'Dynamic Bargaining with Transaction Costs'. Management Science, no. 10, vol. 37, 1221-1233.

Donaldson, L. (1996). 'The Normal Science of Structural Contingency Theory'. Handbook of Organization Studies, S.R. Clegg, C. Hardy, and W.R. Nord (editors), Sage Publications, London, United Kingdom, 57-76.

Fisher, M.L. (1997). 'What is the Right Supply Chain for Your Product?' Harvard Business Review, no. 2, vol. 75, 105-116.

Galbraith, J.R. (1977), Organization Design, Addison-Wesley Publishing Company, Reading, USA

Hengst, M. den (1999). Interorganizational Coordination in Container Transport. A Chain Management Design, Doctoral Dissertation, Delft University of Technology, Delft, the Netherlands.

Hines, P. (1993). 'Integrated Materials Management. The Value Chain Redefined'. International Journal of Logistics Management, no. 1, vol. 4, 13-22.

Huber, G.P. \& Daft, R.L. (1987). 'The Information Environments of Organizations'. Handbook of Organizational Communication. An Interdisciplinary Perspective, F.M. Jablin, L.L. Putnam, K.H. Roberts, and L.W. Porter (editors), Sage Publications, Newbury Park, USA, 130-164.
I\&L (1997). 'Flexibeler door Centrale Organisatie van Logistiek'. Tijdschrift voor Inkoop \& Logistiek, (in Dutch).

Jablin, F.M. (1987). 'Formal Organization Structure'. Handbook of Organizational Communication. An Interdisciplinary Perspective, F.M. Jablin, L.L. Putnam, K.H. Roberts, and L.W. Porter (editors), Sage Publications, Newbury Park, USA, 389-419.

Jarvenpaa, S.L. \& Ives, B. (1994). 'The Global Network Organization of the Future: Information Management Oportunities and Challenges'. Journal of Management Information Systems, no. 4, vol. 10, 25-57.

Kalakota, R. \& Whinston, A.B. (1996). Frontiers of Electronic Commerce, Addison-Wesley Publishing Company, Reading, USA.

Kambil, A. (1992). 'Electronic Integration. A Critical Review and Network Extensions'. Scientific Research on EDI. Bringing Worlds Together, R.J. Streng, C.F. Ekering, E. van Heck, and J.F.H. Schultz (editors), Samson Publishers, 209-231.

Kornelius, L., \& Ekering, C.F. (1994). 'A Framework for Identifying Interorganizational Production Control Needs'. Operations Strategy and Performance. Papers from the 1st International Conference of the European Management Association, Cambridge, United Kingdom, 451-456.

Kotler, P. (1994). Marketing Management. Analysis, Planning, Implementation, and Control, Prentice Hall, Inc., Englewood Cliffs, USA.

Kumar, N. (1996). 'The Power of Trust in Manufacturer-Retailer Relationships'. Harvard Business Review, 92-106.

Levacic, R. (1991). 'Markets'. Markets, Hierarchies and Networks. The Coordination of Social Life, G. Thompson, J. Frances, R. Levacic, and J. Mitchell (editors), Sage Publications, London, United Kingdom, 21-23.

Malone, T.W., \& Rockart, J.F. (1991) 'Computers, Networks and the Corporation'. Scientific American, no. 3, vol. 265, 92-99.

Malone, T.W., \& Crowston, K. (1994). 'The Interdisciplinary Study of Coordination'. ACM Computing Surveys, no. 1, vol. 26, 87119.

Malone, T.W., Yates, J., \& Benjamin, R.I. (1987). 'Electronic Markets and Electronic Hierarchies. Effects of Information Technology on Market Structure and Corporate Strategies'. Communications of the ACM, no. 6, vol. 30, 484-497.

McGrath, J.E. \& Hollingshead, A.B. (1994). Groups Interacting with Technology. Ideas, Evidence, Issues, and an Agenda, Sage Publications, USA.

Miles, R.E. \& Snow, C.C. (1992). 'Causes of Failure in Network Organizations'. California Management Review, Summer, 5372. 
Mintzberg, H. (1993). Structure in Fives. Designing Effective Organizations, Prentice-Hall, Englewood Cliffs, USA.

Monge, P.R. \& Eisenberg, E.M. (1987). 'Emergent Communication Networks'. Handbook of Organizational Communication. An Interdisciplinary Perspective, F.M. Jablin, L.L. Putnam, K.H. Roberts, and L.W. Porter (editors), Sage Publications, Newbury Park, USA, 304-342.

Moore, J.F. (1993). 'Predators and Prey. A New Ecology of Competition', in: Harvard Business Review, no. 3, vol. 71, 75-86.

Moore, N. (1996). 'Creators, Communicators and Consolidators. The New Information Professional'. Managing Information, no. 6 , vol. 3, 24-25.

Porter, M.E. (1980). Competitive Strategy. Techniques for Analyzing Industries and Competitors, Free Press, New York, USA.

Powell, W.W. (1991). 'Neither Market nor Hierarchy, Network Forms of Organization'. Markets, Hierarchies and Networks. The Coordination of Social Life, G. Thompson, J. Frances, R. Levacic, and J. Mitchell (editors), Sage Publications, London, United Kingdom, 265-276.

Rosenschein, J.S. \& Zlotkin, G. (1994). Rules of Encounter. Designing Conventions for Automated Negotiation among Computers, The MIT Press, USA.

Roy, B. (1988). 'Main Sources of Inaccurate Determination, Uncertainty and Imprecision in Decision Models'. Compromise, $\mathrm{Ne}$ gotiation and Group Decision, B.R. Munier and M.F. Shakun (editors), Reidel, Dordrecht, the Netherlands, 43-62.

Sterman, J.D. (1989). 'Modeling Managerial Behavior. Misperceptions of Feedback in a Dynamic Decision Making Experiment'. Management Science, no. 3, vol. 35, 321-339.

Thompson, G., Frances, J., Levacic, R., \& Mitchell, J. (1991). Markets, Hierarchies and Networks. The Coordination of Social Life, Sage Publications, London, United Kingdom.

Thompson, J.D. (1967). Organisations in Action, McGraw-Hill, New York, USA.

Venkatraman, N. (1994). 'IT-Enabled Business Transformation: From Automation to Business Scope Redefinition'. Sloan Management Review, 73-87.

Vreede, G.J. de (1995). Facilitating Organizational Change. The Participative Application of Dynamic Modelling, Doctoral Dissertation, Delft University of Technology, Delft, the Netherlands.

Williamson, O.E. (1975). Markets and Hierarchies, MacMillan, New York, USA.

Williamson, O.E. (1983). 'Credible Commitments: Using Hostages to Support Exchange'. American Economic Review, no. 73, 519-540.
Williamson, O.E. (1985). The Economic Institutions of Capitalism, The Free Press.

Williamson, O.E. (1986). Economic Organization. Firms, Markets and Policy Control, Wheatsheaf Books, United Kingdom.

Winograd, T. \& Flores. F. (1986). Understanding Computers and Cognition: A New Foundation for Design, Alex, Norwoord, USA.

\section{Biographies}

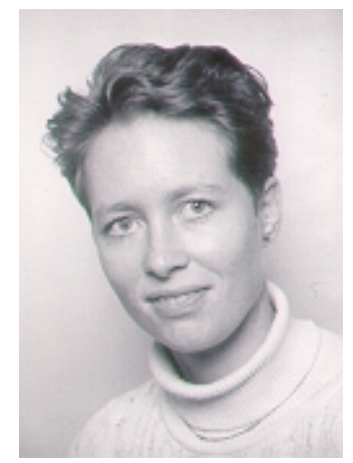

Dr.ir. Mariëlle den Hengst was born on June 5th 1971 in Maassluis, the Netherlands. After graduating from high school, the Scholengemeenschap Spieringshoek in Schiedam, in 1989, she studied computer science at Delft University of Technology specializing in information systems. She graduated cum laude in 1994 with a degree in information technology engineering with a final year thesis on a simulation environment for eliciting information requirements of employees at the Dutch Railroad Company. Immediately after this, she started her Ph.D. thesis research at Delft University of Technology in association with the Research School for Transport, Infrastructure and Logistics. During her research, she presented her work at a number of national and international conferences. She has assisted several master's students with the completion of their final year theses and she has taught courses on information systems and dynamic modeling. She obtained her Ph.D. from the Delft University of Technology on the subject of 'Interorganizational Coordination in Container Transport; a chain management design' in October of 1999. Her research focused on designing an ICT based system for chain management in container transport. Currently, she is an assistant professor at the faculty of Technology, Policy and Management at Delft University of Technology.

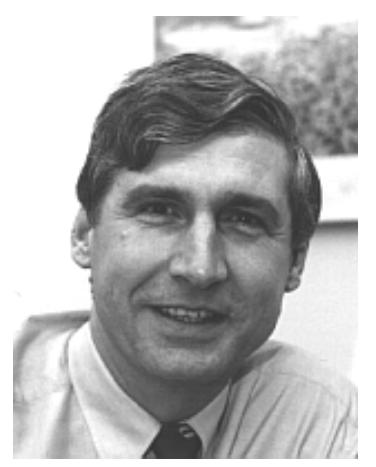

Prof.dr. Henk G. Sol (1951) obtained a Ph.D. from the University of Groningen on the subject of 'Simulation in Information Systems Development' in 1982. Dr. Sol became a chaired professor of 'Information Systems Development' at Delft University of Technology in 1984, where he developed the Depart- 
ment of Information Systems. In 1992 Prof. Sol was appointed as chaired professor of 'Systems Engineering'. From $1992-1998$ he was founding Dean of the new School for Engineering, Policy Analysis and Management. His research focuses on the development of services enabled by ict, management information systems, decision support systems and telematics. Currently his research interest shifts towards designing information-intensive, innovative organizations. He is a well-known author with a few hundred publications in these fields and organized numerous international conferences and workshops and gave a great many invited presentations. He serves on the editorial board of such journals as Information and Management, Decision Support Systems, European Journal of Information Systems, Organizational Science, Communications of AIS. He is member of IFIP TC 8, W.G. 8.1, 8.2, 8.4 and various other professional organizations. He received the IFIP Outstanding Service Award as well as the IFIP Silver Core. 